\title{
Gambaran NAFLD pada Pasien dengan Sindrom Metabolik di Poliklinik Penyakit Dalam RSUP Dr. M. Djamil Padang
}

\author{
Nadila Andam Astari ${ }^{1}$, Eva Decroli $^{2}$, Eti Yerizel $^{3}$
}

\begin{abstract}
Abstrak
Sindrom metabolik adalah kumpulan faktor risiko penyakit kardiovaskular yang terjadi secara bersamaan pada seorang individu, antara lain: peningkatan glukosa darah puasa, obesitas sentral, dislipidemia, dan hipertensi. Salah satu manifestasi sindrom metabolik adalah non alcoholic fatty liver disease (NAFLD). Tujuan penelitian ini adalah untuk mengetahui gambaran NAFLD pada pasien dengan sindrom metabolik di poliklinik penyakit dalam RSUP Dr. M. Djamil Padang. Penelitian ini bersifat deskriptif dengan bentuk cross sectional dan pendekatan retrospektif menggunakan data primer berupa hasil USG hati dan lingkar perut serta data sekunder berupa data rekam medis hasil pemeriksaan tekanan darah dan lab darah (gula darah, kolesterol, dan trigliserida) pasien dengan sindrom metabolik di RSUP Dr. M. Djamil Padang periode Oktober 2013 - Agustus 2014. Dari 30 subjek yang didapatkan, didapatkan 20 diantaranya menderita NAFLD (67\%). Dari 20 orang penderita NAFLD, 20 orang (100\%) obesitas sentral, 19 orang $(95 \%)$ menderita gula darah puasa terganggu, 13 orang $(65 \%)$ mengalami peningkatan trigliserida darah, 13 orang (65\%) mengalami penurunan kadar HDL darah, dan 15 orang $(75 \%)$ hipertensi.
\end{abstract}

Kata kunci: sindrom metabolik, NAFLD, obesitas

\begin{abstract}
Metabolic syndrome is a set of cardiovascular disease risk factors that occur simultaneously on an individual, i.e. increase in fasting blood sugar, central obesity, dyslipidemia, and hypertension. Non alcoholic fatty liver disease (NAFLD) is one of the manifestations of metabolic syndrome. The objective of this study was to determine description of NAFLD on patients with metabolic syndrome at internal medicine polyclinic RSUP. Dr. M. Djamil Padang. Descriptive research has been conducted with a cross-sectional study and a retrospective approach using liver USG result and waist circumference as primary data and medical record of blood pressure and lab (triglyceride, HDL, fasting blood sugar) as secondary data on patients with metabolic syndrome at RSUP Dr. M. Djamil Padang during October 2013 - August 2014. The result of this study showed 20 cases of NAFLD (67\%) from 30 subjects found. From those 20 cases, 20 have central obesity (100\%), 19 have impaired fasting blood sugar (95\%), 13 have hypertriglyceridemia (65\%), 13 have decrease of blood HDL level (65\%), and 15 have hypertension (75\%).
\end{abstract}

Keywords: metabolic syndrome, NAFLD, obesity

Affiliasi penulis: 1. Pendidikan dokter FK UNAND (Fakultas Kedokteran Universitas Andalas Padang), 2. Bagian IImu Penyakit Dalam FK UNAND, 3. Bagian Biokimia FK UNAND

Korespondensi: Nadila Andam Astari, E-mail: nadila.star@gmail.com, Telp: 081266580680

\section{PENDAHULUAN}

Dalam beberapa dekade terakhir, gaya hidup modern telah menyebabkan perubahan dramatis status masyarakat dari undernutrition menjadi overnutrition. Akibatnya terjadi peningkatan prevalensi obesitas dan penyakit terkait obesitas, salah satunya adalah sindrom metabolik. Sindrom metabolik, atau diperkenalkan sebagai Sindrom $X$ oleh Reaven, didefinisikan sebagai kumpulan faktor risiko penyakitpenyakit kardiovaskular yang terjadi secara bersamaan pada seorang individu. Faktor-faktor risiko tersebut antara lain: peningkatan glukosa darah puasa, obesitas abdominal, hiperkolesterolemia, dan hipertensi. ${ }^{1}$ 
Akumulasi lemak yang berlebihan dalam tubuh diduga merupakan penyebab utama yang mendasari timbulnya sindrom metabolik. Salah satu faktor yang berkontribusi besar adalah gaya hidup, yaitu gaya hidup modern dengan tingkat stress tinggi, pola makan yang tidak sehat, dan inaktivitas fisik. Gaya hidup seperti ini akan menyebabkan penumpukan lemak viseral. Penumpukan lemak viseral yang berlebihan sering didapat pada keadaan obesitas sentral. ${ }^{2}$

Obesitas adalah keadaan akumulasi lemak yang abnormal atau berlebihan di tubuh. Sedangkan obesitas sentral atau disebut juga obesitas abdominal adalah penumpukan lemak yang berlebihan di daerah peritoneum. Penumpukan lemak di daerah peritoneum lebih berbahaya dibandingkan penumpukan di daerah subkutan. Hal ini disebabkan jaringan adiposa viseral memiliki potensial lipolitik yang lebih tinggi. Selain itu pelepasan asam lemak bebas dari jaringan ini akan langsung menuju sirkulasi portal. Penelitian menunjukkan bahwa area lemak viseral, dihitung dengan CT Scan pada level umbilikalis, berkorelasi secara signifikan dengan kadar glukosa pada tes toleransi glukosa, plasma trigliserida, dan level kolesterol pada subjek yang obesitas. Obesitas berkaitan erat dengan penyakit-penyakit kronis, seperti diabetes, penyakit kardiovaskuler dan kanker. Metode pengukuran obesitas adalah dengan menghitung Indeks Masa Tubuh (IMT). Seseorang dikatakan obesitas dengan IMT $>30$. $^{3}$

Peningkatan asam lemak bebas dalam tubuh juga merupakan mediator utama terjadinya resistensi insulin. Resistensi insulin atau hiperinsulinemia adalah suatu keadaan berkurangnya kemampuan sel tubuh merespon terhadap insulin. Resistensi insulin menimbulkan penyakit diabetes melitus tipe 2 dan mendasari kelainan pada sindrom metabolik lainnya. ${ }^{4}$

Kriteria diagnostik sindrom metabolik (SM) antara lain adalah peningkatan kadar trigliserida serum (>150 mg/dL) yang biasanya diikuti dengan penurunan kadar kolesterol HDL $(<40 \mathrm{mg} / \mathrm{dL}$ pada pria dan $<50 \mathrm{mg} / \mathrm{dL}$ pada wanita). Kadar glukosa darah puasa digunakan sebagai indikator resistensi insulin dengan nilai $\geq 100 \mathrm{mg} / \mathrm{dL}$. Penentuan obesitas sentral dilakukan dengan pengukuran lingkar perut. Kriteria obesitas sentral adalah $\geq 90 \mathrm{~cm}$ pada pria dan $\geq 80$ pada wanita. Selain itu pada pasien dengan sindrom metabolik didapat peningkatan tekanan darah, yaitu $\geq$ $130 \mathrm{mmHg}$ sistolik dan $\geq 85 \mathrm{mmHg}$ diastolik. ${ }^{1}$

Salah satu manifestasi dari sindrom metabolik adalah Nonalcoholic Fatty Liver Disease (NAFLD). American Association for the Study of Liver Disease mendefinisikan NAFLD sebagai didapatkannya steatosis hepatic, baik secara imaging dengan alat USG maupun secara histologis, tanpa adanya sebab akumulasi lemak hepatik sekunder seperti konsumsi alkohol yang signifikan, penggunaan obat-obatan steatogenik, atau penyakit turunan. Steatosis didefinisikan sebagai akumulasi trigliserida dalam bentuk makrovakuola di dalam sitoplasma hepatosit. ${ }^{5}$ Sebanyak $15-50 \%$ akan berlanjut menjadi fibrosis atau sirosis hepatis dengan mortalitas $10 \%{ }^{6}$

Akumulasi lemak di sel hati disebabkan oleh peningkatan aliran asam lemak bebas dari lapisan lemak viseral ke hati melalui vena portal. Di dalam hepatosit, resistensi insulin dan asam lemak bebas yang berlebihan dapat menganggu oksidasi asam lemak oleh mitokondria. $\mathrm{Hal}$ ini menyebabkan akumulasi lemak di hepatosit. ${ }^{7}$ Spektrum NAFLD meliputi steatosis (perlemakan), steatohepatitis (perlemakan dan peradangan hati), Non-alcoholic steatohepatitis (NASH), fibrosis hati dan sirosis hati. ${ }^{8}$

Prevalensi NAFLD di dunia meningkat pesat, selaras dengan peningkatan kejadian diabetes melitus tipe 2, obesitas, dan hiperlipidemia. Diperkirakan $17-$ $33 \%$ populasi umum mengalami NAFLD dan meningkat hingga 30-100\% pada penderita obesitas. Pada pasien bedah bariatric dengan indikasi obesitas berat, prevalensi NAFLD lebih dari $90 \%$ dan $5 \%$ sirosis yang tidak diduga. Studi USG pada pasien dengan Diabetes Melitus tipe 2 menunjukkan angka prevalensi NAFLD $69 \%{ }^{9}$

Diagnosis NAFLD dapat ditegakkan baik secara histology (biopsi) maupun melalui imaging. Keberadaan lemak $>33 \%$ dianggap optimal untuk mendeteksi perlemakan hati secara radiologis. Pada USG, perlemakan hati ditemukan sebagai bright liver yang merupakan peningkatan echogenicity jika dibandingkan dengan ginjal di dekatnya. ${ }^{10}$

Pasien dengan NAFLD cenderung tidak memiliki gejala yang khas, beberapa asimtomatik. Adapun keluhan yang sering muncul adalah keluhan pada perut kanan atas dan intoleransi fisik, seperti 
mudah lelah dan sakit kepala. Kriteria sindrom metabolik berdasarkan IDF dipilih karena kriteria ini adalah yang terbaru serta memiliki pengukuran lingkar pinggang tersendiri untuk ras di Asia. Kumpulan gejala sindrom metabolik yang dimiliki seseorang bisa menjadi pemeriksaan dini risiko terhadap NAFLD. Oleh sebab itu, penelitian mengenai frekuensi NAFLD pada penderita sindrom metabolik di poliklinik penyakit dalam RSUP Dr. M. Djamil Padang ini perlu dilakukan.

\section{METODE}

Jenis penelitian adalah penelitian deskriptif dengan menggunakan metode cross sectional dimana sindrom metabolik sebagai faktor risiko dan non alcoholic fatty liver disease sebagai efek yang diteliti. Penelitian dilakukan di poliklinik penyakit dalam RSUP Dr. M. Djamil Padang dari Oktober 2013 sampai Agustus 2014.

Populasi penelitian ini adalah seluruh pasien yang berobat ke poliklinik penyakit dalam RSUP Dr. M. Djamil Padang. Subjek adalah semua penderita sindrom metabolik dewasa yang datang berobat ke poliklinik RSUP. Dr. M. Djamil Padang yang memenuhi kriteria inklusi pada saat penelitian berjalan. Pengambilan sampel dilakukan dengan metode purposive sampling. Kriteria inklusi sampel adalah berusia 18-70 tahun, memenuhi kriteris sindrom metabolik menurut IDF dan bersedia mengikuti penelitian. Kriteria eksklusi sampel adalah memiliki riwayat hepatitis, riwayat peminum alkohol, dan mengonsumsi obat-obatan yang dapat menyebabkan perlemakan hati.

Subjek yang memenuhi kriteria obesitas sentral diukur lingkar perutnya. Data rekam medis berupa kadar gula darah puasa, tekanan darah, HDL, dan trigliserida darah dikumpulkan dan dilakukan pencatatan data. Pemeriksaan USG kemudian dilakukan kepada sampel yang memenuhi kriteria sindrom metabolik.Interpretasi hasil USG kemudian dikumpulkan untuk dilakukan pengolahan data.

\section{HASIL}

Pada penelitian yang di lakukan di Poliklinik Penyakit Dalam RSUP Dr. M. Djamil Padang ini didapatkan 30 pasien dengan sindrom metabolik. Dari 30 pasien tersebut terdapat 20 orang (67\%) yang didiagnosis Non Alcoholic Fatty Liver Disease.

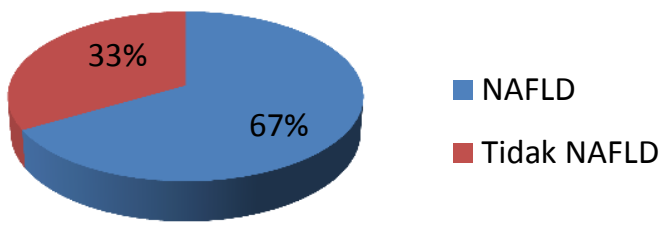

Gambar 1. Non alcoholic fatty liver disease pada pasien dengan sindrom metabolik

Jenis kelamin penderita NAFLD pada SM terdiri atas 10 orang laki-laki (50\%) dan 10 orang perempuan (50\%). Usia berkisar 50-69 tahun dengan rerata +simpang baku 57,5 +- 5,57 tahun dan nilai tengah 57 tahun. Penderita NAFLD terbanyak terdapat pada kelompok usia 50-59 tahun yaitu sebanyak 11 orang, diantaranya 7 orang laki-laki dan 4 orang perempuan, diikuti dengan kelompok usia 60-69 tahun yaitu 9 orang, diantaranya 3 laki-laki dan 4 perempuan.

Tabel 1. Data demografi, parameter klinik, dan hasil labor 20 pasien NAFLD

\begin{tabular}{|c|c|c|c|c|}
\hline & Normal & Kisaran & $\begin{array}{l}\text { Rerata } \pm \\
\text { Simpang }\end{array}$ & $\begin{array}{l}\text { Nilai } \\
\text { Tengah }\end{array}$ \\
\hline Usia (tahun) & & $50-69$ & $\overline{59,1} \pm 5,3$ & 58,5 \\
\hline $\begin{array}{l}\text { Lingkar perut } \\
\text { (cm) }\end{array}$ & $\begin{array}{l}<90 \\
\text { (pria) }\end{array}$ & $86-125$ & $\begin{array}{l}103,65 \pm \\
11,58\end{array}$ & 100,5 \\
\hline $\begin{array}{l}\text { Hipertensi } \\
(\mathrm{mmHg})\end{array}$ & $\begin{array}{l}<130 \\
\text { (sistol) }\end{array}$ & $\begin{array}{l}90 / 70- \\
180 / 110\end{array}$ & $\begin{array}{l}142 \pm \\
19,08 / 84,5 \pm\end{array}$ & $145 / 87,5$ \\
\hline Gúla därah " " & $<\hat{100} 0$ & $98-360$ & $\hat{178,22 \pm ~}$ & 132,5 \\
\hline $\begin{array}{l}\text { (ma/dL) } \\
\text { Kadar } \\
\text { trigliserida }\end{array}$ & $<150$ & $108-361$ & $\begin{array}{l}84.29 \\
180,95 \pm \\
61,93\end{array}$ & 176,5 \\
\hline $\begin{array}{l}\text { Kadar HDL } \\
(\mathrm{mg} / \mathrm{dL})\end{array}$ & $\begin{array}{l}>40 \\
\text { (pria) }\end{array}$ & $24-58$ & $40,35 \pm 7,80$ & 41,5 \\
\hline & $>50$ & & & \\
\hline
\end{tabular}

Pada pasien NAFLD, didapatkan jumlah pasien dengan obesitas sentral sebanyak $100 \%$, gula darah puasa terganggu sebanyak $95 \%$, hipertensi sebanyak $75 \%$, hipertrigliseridemia sebanyak 65\%, dan kadarHDL darah rendah sebanyak $65 \%$. 
Tabel 2. Proporsi komponen sindrom metabolik pada pasien yang menderita NAFLD

\begin{tabular}{ll}
\hline Kriteria Sindrom Metabolik & NAFLD \\
\hline Obesitas sentral & $100 \%$ \\
Gula Darah Puasa Terganggu & $95 \%$ \\
Hipertensi & $75 \%$ \\
Hipertrigliseridemia & $65 \%$ \\
HDL rendah & $65 \%$ \\
\hline
\end{tabular}

Komponen sindrom metabolik terdiri dari obesitas sentral, GDPT, kadar trigliserida tinggi, kadar HDL rendah, dan hipertensi. Pada penelitian ini dilakukan pembagian sindrom metabolik berdasarkan jumlah komponen yang terganggu, yaitu 3 komponen, 4 komponen, dan 5 komponen. Dari 20 pasien NAFLD terdapat 6 pasien (30\%) dengan 3 komponen yang terganggu, 7 pasien (35\%) dengan 4 komponen yang terganggu, dan 7 pasien (35\%) dengan 5 komponen yang terganggu.

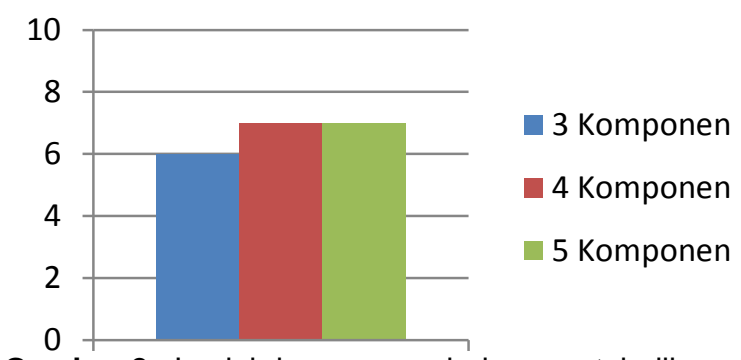

Gambar 2. Jumlah komponen sindrom metabolik pada penderita NAFLD

\section{PEMBAHASAN}

Sindrom metabolik merupakan salah satu dari banyak faktor risiko. ${ }^{11}$ Adanya peningkatan prevalensi sindrom metabolik menyebabkan peningkatan kejadian NAFLD yang merupakan manifestasi kelainan hati pada sindrom metabolik. Penelitian mengenai NAFLD menghasilkan angka yang bervariasi karena perbedaan populasi dan metode yang digunakan. ${ }^{9}$ Penelitian ini dilakukan terhadap pasien dengan sindrom metabolik yang datang berobat ke Poliklinik Penyakit Dalam RSUP Dr. M. Djamil Padang.

Pada penelitian ini didapatkan 30 pasien dengan sindrom metabolik. Dari 30 pasien, terdapat 20 orang $(67 \%)$ yang didiagnosis NAFLD. Sindrom metabolik berpengaruh besar dalam akumulasi lemak hepar. Pada penelitian oleh Andrada \& Tan di tahun 2006, berdasarkan hasil USG hepar 109 penderita NAFLD, 51\% diantaranya memenuhi kriteria sindrom metabolik. ${ }^{12}$ Penelitian lain di RSUP Dr. Kariadi Semarang oleh Sari (2012) mendapatkan 72\% dari pasien NAFLD memenuhi kriteria sindrom metabolik. $^{13}$ Pemeriksaan dilakukan menggunakan alat ultrasonografi (USG). Akumulasi lemak di hepar menyebabkan peningkatan densitas, sehingga menimbulkan gambaran bright liver pada NAFLD dan cenderung menyebabkan visualisasi dinding pembuluh darah berkurang. ${ }^{10}$

Perbandingan (rasio) antara penderita NAFLD laki-laki dan perempuan adalah 1 : 1 (50\%:50\%). Hal ini selaras dengan penelitian oleh American Gastroenterogical Association (AGA) pada tahun 2002 yang menunjukkan frekuensi penderita NAFLD lakilaki dan perempuan sama. ${ }^{14}$ Usia penderita NAFLD pada sindrom metabolik berkisar antara 50-69 tahun, dengan rerata \pm simpang baku 59,1 \pm 5 ,3. Sebagian besar penderita adalah kelompok usia 50-59 tahun. NAFLD dapat terjadi pada semua umur, namun kelompok yang memiliki risiko tertinggi adalah kelompok usia 40-65 tahun. ${ }^{11}$ Sejumlah penelitian menyatakan bahwa risiko NAFLD meningkat bersamaan dengan meningkatnya usia. Hal ini disebabkan karena peningkatan usia menyebabkan peningkatan risiko seseorang menderita faktor risiko dari NAFLD, seperti diabetes melitus, obesitas, hipertensi, dan dislipidemia. ${ }^{15}$

Diabetes melitus, dislipidemia, dan obesitas sering dikaitkan dengan NAFLD. Penelitian di negara maju, prevalensi NAFLD adalah $60 \%$ pada populasi obesitas, $70 \%$ pada pasien DM, dan sekitar $60 \%$ pada pasien dislipidemia. ${ }^{8}$ Prevalensi NAFLD di Indonesia pada populasi risiko tinggi adalah $\sim 52 \%$ pada populasi dengan DM tipe 2, $\sim 47 \%$ pada populasi dengan obesitas sentral, dan $\sim 56 \%$ pada populasi dengan dislipidemia. ${ }^{16}$ Penelitian ini menggunakan kriteria sindrom metabolik dari International Diabetes Federation, sehingga semua pasien yang mengikuti penelitian ini (100\%) obesitas sentral. Obesitas adalah faktor risiko yang sangat berpengaruh NAFLD. Steatosis muncul jika input asam lemak bebas 
melebihi output yang terjadi pada orang obese. ${ }^{17}$

Keadaan gula darah puasa terganggu pada penderita NAFLD sangat tinggi, yaitu 95\%. Peningkatan kadar gula darah puasa disebabkan oleh resistensi insulin. Insulin berperan dalam uptake glukosa ke dalam sel. Pada keadaan resistensi insulin, terjadi gangguan di tingkat reseptor insulin sehingga menghambat sinyal untuk melakukan proses metabolisme glukosa di dalam sel. Hal ini menyebabkan sintesis insulin terganggu sehingga terjadi defisiensi insulin. Berkurangnya insulin menyebabkan uptake glukosa sel menurun dan kadar glukosa darah meningkat (hiperglikemia). Hal ini menyebabkan jaringan yang membutuhkan energi tidak mendapatkan energi yang cukup, sehingga dibutuhkan energi dari lemak tubuh melalui lipolisis. ${ }^{18}$ Proses lipolisis ini menyebabkan peningkatan asam lemak bebas dalam tubuh, yang juga akan menyebabkan keadaan dislipidemia, dan menyebabkan penumpukan sel lemak di hepar.

Pada penelitian ini didapatkan angka dislipidemia 50\%, hipertrigliseridemia $65 \%$ dan kadar HDL rendah 65\%. Dislipidemia adalah komponen sindrom metabolik yang sering muncul pada NAFLD. Dislipidemia pada NAFLD menurut IDF memiliki karakteristik peningkatan kadar trigliserida darah dan penurunan kadar HDL darah. ${ }^{1}$ Dislipidemia pada NAFLD terjadi karena asupan kalori, terutama karbohidrat dan lemak yang berlebihan. Asupan kalori ini akan menyebabkan peningkatan kadar asam lemak bebas dalam darah yang nantinya akan mengalami proses esterifikasi menjadi trigliserida. Selanjutnya akan terjadi juga peningkatan VLDL yang berfungsi sebagai sekresi lipoprotein kaya trigliserida dari hati ke sirkulasi namun tidak dapat mengimbangi peningkatan trigliserida yang drastis, sehingga kelebihan dari trigliserida akan di simpan sebagai sel-sel lemak di hati. Peningkatan VLDL juga menyebabkan berkurangnya aliran apolipoprotein dan fosfolipid yang diperlukan untuk maturisasi HDL. Enzim cholesteryl ester transfer protein (CETP) berkontribusi dalam pemindahan kolesteril ester dari HDL ke lipoprotein kaya trigliserida (kilomikron dan VLDL) sehingga terjadi penurunan kadar HDL dalam darah. ${ }^{19}$ Hal ini sesuai dengan karakteristik dislipidemia pada NAFLD.
Komponen sindrom metabolik lain adalah peningkatan tekanan darah. Pada penelitian ini didapatkan angka hipertensi $75 \%$. Penelitian oleh Andrada\& Tan pada tahun 2006, mendapatkan angka hipertensi sebanyak $66,1 \% .{ }^{12}$ Pada resistensi insulin, ketidakseimbangan antara pressor dan depressor menyebabkan peningkatan pembuluh darah. ${ }^{20}$

Tidak terdapat perbedaan yang signifikan pada pembagian sindrom metabolik berdasarkan jumlah komponennya. Dari penelitian ini didapatkan 6 pasien (30\%) dengan 3 komponen yang terganggu, 7 pasien (35\%) dengan 4 komponen yang terganggu, dan 7 pasien (35\%) dengan 5 komponen yang terganggu. Hasil ini juga ditemukan pada penelitian mengenai hubungan jumlah komponen sindrom metabolik dengan derajat perlemakan hati yang menunjukkan tidak ada hubungan diantara keduanya. ${ }^{13}$

\section{KESIMPULAN}

Dua pertiga (67\%) pasien sindrom metabolik yang berobat di Poliklinik Penyakit Dalam RSUP Dr. M. Djamil menderita non alcoholic fatty liver disease.

Kriteria sindrom metabolik terbanyak pada penderita non alcoholic fatty liver disease secara berurutan adalah obesitas sentral, gula darah puasa terganggu, hipertensi, kadar trigliserida darah tinggi, dan kadar HDL darah rendah.

\section{DAFTAR PUSTAKA}

1. Alberti SG, Zimmet P, Shaw J, Grundy SM.The IDF consensus worldwide definition of the metabolic syndrome. Brussel: International Diabetes Federation; 2006.

2. Angulo P. GI Epidemiology: nonalcoholic fatty liver disease. Alimentary Pharmacology \& Therapeutics. 2007;25(8):883-9.

3. Matsuzawa Y. Obesity as an endocrine disease. Dalam: Kopelman PG, Caterson ID, Dietz WH, editor. Clinical Obesity in Adults and Children. Edisi ke-3. 2010. Oxford: Blackwell Publishing Limited. hlm. 200-7.

4. Expert Panel on Detection, Evaluation, and Treatment of High Blood Cholesterol in Adults. Executive Summary of the Third National Report of the National Cholesterol Education Program 
(NCEP) Expert Panel on Detection, Evaluation, and Treatment of High Blood Cholesterol in Adults(ATP III). 2001

5. Kawano Y, Cohen DE. Mechanisms of hepatic triglyceride accumulation in non-alcoholic fatty liver disease. Journal of Gastroenterology. 2013;48(4):434-41.

6. Sears D. Fatty liver. [sumber online]. 2012 (diunduh 22 Oktober 2013). Tersedia dari: URL: HYPERLINK http://emedicine.medscape.com/ article/175472-overview.

7. Palasciano G, Moschetta A, Palmieri VO, Grattaqliano I, lacobellis G, Portincasa P. Nonalcoholic fatty liver disease in the metabolic syndrome. Current Pharmaceutical Design. 2007;13(21):2190-8.

8. Hasan I. Perlemakan hati non alkoholik. Dalam: Sudoyo AW, Setiyohadi B, Alwi I, Simadibrata M, Setiati S, editor (penyunting). Buku Ajar IImu Penyakit Dalam Edisi ke-5. Jakarta: Interna Publishing; 2009. hlm. 695-701.

9. Chalasani N, Lavine JE, Diehl AM, Brunt EM, Cusi $\mathrm{K}$, et al. The diagnosis and management of nonalcoholic fatty liver disease: practice guideline by the American association for the study of liver diseases, American College of Gastroenterology, and the American Gastroenterological Association. Hepatology. 2012;55(6):2005-23.

10. Pedersen OM, Ødegaard S. Ultrasonography of the Liver, biliary system and pancreas. Dalam: Ødegaard S, Gilja OH, Gregersen H, editor (penyunting). Basic and New Aspects of Gastrointestinal Ultrasonography. Singapore: World Scientific Publishing Co; 2005. hlm. 75-140.

11. Douglas L, Abbas Z, Anania F. Nonalcoholic fatty liver disease and nonalcoholic steatohepatitis,
Milwaukee: World Gastroenterology Organisation; 2012.

12. Andrada PL, Tan J. Prevalence of metabolic syndrome among patients with non-alcoholic liver disease. Phil J Gastroenterol. 2006;2:14-8.

13. Sari G. Penyakit perlemakan hati non-alkoholik pada sindroma metabolik dewasa. Semarang: Fakultas Kedokteran Universitas Diponegoro; 2012.

14. American Gastroenterogical Association. Technical review on nonalcoholic fatty liver disease. Gastronterol. 2002;123:1705-25.

15. Vernon G, Baranova A, Younossi ZM. Systematic review: the epidemiology and natural history of non-alcoholic fatty liver disease and non-alcoholic steatohepatitis in adults. Alimentary Pharmacology and Therapeutics. 2011;34:274-285.

16. Amarapurkar D, Hashimoto E,Lesmana L. How common is non-alcoholic fatty liver disease in the Asia-pacific Region and are there local differences?.Journal of Gastroenterology and Hepatology. 2007;22(6):788-93.

17. Fabbrini E, Sullivan S, Klein S. Obesity and nonalcoholic fatty liver: biochemical, metabolic, and clinical implication. Hepatology. 2010;51(2):679-89.

18. Klop B, Elte JWF, Cabezas MC. Dyslipidemia in obesity: mechanisms and potential targets. Nutrients. 2013;5(4):1218-40.

19. Franssen R, Monajemi H, Stroes E. Obesity and dyslipidemia. Endocrinology and Metabolism Clinics of North America. 2008;37:623-33.

20. Soegondo S, Purnamasari D. Sindrom metabolik. Dalam: Sudoyo AW, Setiyohadi B, Alwi I, Simadibrata M, Setiati S, editor (penyunting). Buku Ajar IImu Penyakit Dalam. Edisi ke-5. Jakarta: Interna Publishing 2009. hlm1865-72. 